\title{
O FRIO (DE COMO TERIA SIDO O ILUSTRE D. SEBASTIÃO I DE PORTUGAL O INVENTOR DA AUTOFICÇÃO)
}

Luís Roberto de Souza Júnior ${ }^{1}$

Em 4 de Agosto de 1578, data que poderia ser para sempre conhecida como "o dia da infâmia" em Portugal, o santo rei D. Sebastião, o amado infante D. Sebastião, "o desejado", o que tinha seis dedos num dos pés, mas mesmo assim era perfeito, o ilustríssimo monarca português e brasileiro submeteu-se de bom grado à Batalha de Alcácer-Quibir, no norte de Marrocos. O desaparecimento de D. Sebastião deu origem ao mito do Sebastianismo, já que corpo real nunca foi encontrado e ainda bá os que acreditam que ele voltará. O que os historiadores nunca entenderam foi porque, contra todos os prognósticos, D. Sebastião insistiu em liderar um esfomeado exército de no máximo vinte mil homens contra uma vigorosa armada de cento e vinte mil marroquinos e otomanos. Até que recentemente, em pesquisas na aldeia de Suaken, ao que tudo indica o local da batalba e onde bá um em memória de D. Sebastião, um texto de próprio punho do santo rei desvendou o mistério secular. Publicamos a carta a seguir com as devidas adaptacões ao português de hoje. Como se nota, é inegável que D. Sebastião (que, apesar do imenso desejo de toda o país luso, não deixou descendência), possuia razoável técnica literária. Mais: ele teria sido o inventor da autoficção quase quatro séculos antes de o crítico literário francês Serge Doubrovsky cunbar o termo em 1977.

“O frio começava nos pés, seus pés, mais o de seis dedos (talvez por ter maior superfície), estavam sempre frios, em quase 24 anos não houve um dia sem frio nos pés, mesmo com as longas meias que modelavam as pernas até o calção tufado de espada. E a situação só piorava quando, mesmo que mantivessem as meias, tirassem o calção e o gibão cintado com gorgeira alta de linho e, obviamente, também a capa curta.

Então subia pela perna, o frio, subia sem arrepiar os pelos, se os pelos se arrepiassem seria bom, seria sinal de calor, não de frio, daquele frio que contornava a batata das pernas e passava pelos joelhos, ganhando as coxas e chegando ao lugar onde deveria sentir um calor nesses momentos em que uma cortesã, mais uma, tirava a saia rodada sobre a estrutura

\footnotetext{
${ }^{1}$ Mestrando em Letra PUCRS, área de concentração Teoria da Literatura, bolsista CNPQ, linha de pesquisa Escrita Criativa.
} 
metálica em cone, o corpete rígido costurado a varetas metálicas com duas ordens de mangas e gorgeira frufruosa.

Mesmo se não fosse o frio, chegava a pensar o infante que não era mais infante, seria complicado manter-se rígido perante a tanta roupa e tanta estrutura a ser tirada da cortesã.

E era um fato que ele não se mantinha rígido. Rígido ali só mesmo o corpete da cortesã, da cortesã que agora estava só com algumas rendas e jóias, e o infante que não era mais infante já fazia algum tempo sentia-se mole e, sobretudo, friorento.

E o lugar em que deveria sentir calor nesse momento mais parecia um feijão, um grãozinho (quase do tamanho, alguns diziam que era menor, outros um pouco maior, de seu dedo adicional no pé) de feijão que não prosperou, ou uma lagarta que não virou borboleta e não conduziu em suas asas a cortesão e o infante que havia muito não era infante.

Nesses momentos, que se repetiam, o infante que não infante (e talvez nunca tenha sido exatamente um infante) só pensava em fugir, em "s'enfuir", porque ele gostava de pensar em francês que era mais chique. Mas ele não pensava em fugir para a França (ele mantinha relações com seu amiguinho - pois se conheciam desde a infância - Luís Algum Número). Não, ele queria fugir para a África, e claro que não seria para ter um harém, um harém para ele seria o Pólo Norte, ele queria o calor do deserto, um monte de africanos fortes para conquistar, para dominar. Ou ser dominado, era um risco, grande segundo seus conselheiros, inclusive mamãe e o tio Felipe. Então ele hesitava, sabia que era esperavam muito dele, sempre esperaram, vovó Catarina principalmente.

Mas há coisas na vida que não se podem evitar. E o lugar dele não era na corte, era no calor da batalha, no corpo a corpo, bem longe das cortesãs. E, se morresse, o que seria a morte perto daquele frio que nunca deixaria de sentir?” 